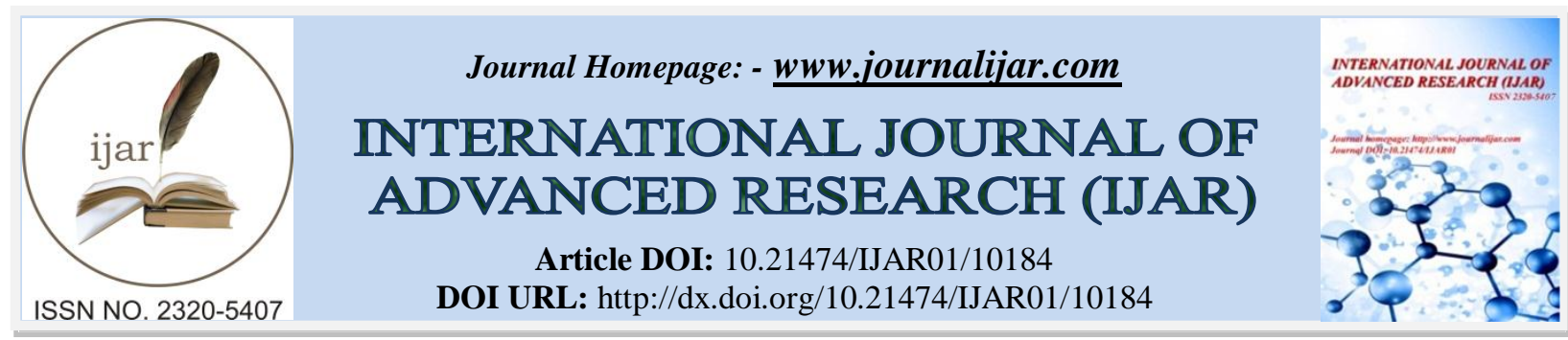

RESEARCH ARTICLE

\title{
INCREASING REGIONAL COMPETITIVENESS THROUGH SUPERIOR AGROINDUSTRY PRODUCTS
}

\author{
Shanti Kirana Anggraeni ${ }^{1,3}$, M. Syamsul Maarif ${ }^{2}$, Sukardi $^{3}$ and Sapta Raharja ${ }^{3}$ \\ 1. Industrial Engineering Department, Faculty of Engineering, Sultan Ageng Tirtayasa University, Banten, \\ Indonesia. \\ 2. Business School - IPB University (Bogor Agricultural University), Bogor, Indonesia. \\ 3. Department of Agroindustrial Technology, IPB University (Bogor Agricultural University), PO BOX 220 \\ 16602, Bogor, Indonesia.
}

\section{Manuscript Info}

\section{Manuscript History}

Received: 08 October 2019

Final Accepted: 10 November 2019

Published: December 2019

Keywords:-

Competitiveness, Regional Potential, Superior Products

\section{Abstract}

Efforts to improve regional competitiveness are important and one of them is by determining the superior products which are in line with regional potential. The purpose of this study is to determine the criteria for superior products, followed by determining the priority of superior products in fish processing agro-industries in Banten Province. From the results of calculations using the Eckenrode method obtained criteria for superior products namely regional uniqueness / characteristic criteria (0.121), followed by raw material criteria (0.102), market absorption (0.099), collaboration network (0.097), technology (0.096), human resources (0.085), economic contributions (0.079), environmentally friendly (0.076), socio-cultural contributions (0.070), quality assurance and food safety (0.061), risk (0.058), and working capital (0.056). Furthermore, the TOPSIS method obtained the priority of superior processed fish products from Banten Province, namely milkfish satay.

CopyRight, IJAR, 2019, All rights reserved.

\section{Introduction:-}

Globalization is believed to have various impacts. Globalization can open opportunities to expand domestic product markets to partner countries. Conversely, negative impacts will be felt, especially by companies that have low competitiveness. Globalization has caused all industries to deal directly with increasingly intense competition. No exception for agroindustry with small and medium scale businesses in the area. This condition requires industries in the regions to be able to increase their competitiveness in order to be able to lift regional competitiveness, towards strengthening national competitiveness.

One area in Indonesia, namely Banten Province, has a variety of fish processing agro-industries and is spread throughout the region. Fish processing agro-industry is an industry that uses fish as raw material to be processed through transformation and preservation by means of a process of physical or chemical change, storage, packaging, and distribution to produce products with higher added value. Most of the varieties of fish processing agro-industry products are food products, while non-food processed fish products can be food or pharmaceutical products. The diverse types of processed fish products in Banten Province have not been accompanied by competitive advantages in the face of increasingly fierce global competition. Processed fish products which are mostly produced and 
marketed by small-scale micro-scale industries (SMEs) still face various problems such as low product shelf life, packaging and label designs that are not standard, low achievement of certified products, and marketing that only rely on the local market (Hasibuan, 2015; Anggraeni et al., 2017; Alfarisi et al., 2018; Ridloudin et al., 2019).

Looking at the various real conditions of developing fish processing units in Banten Province today, it shows that it takes a lot of new breakthroughs or innovations as solutions to improvements. So that product improvement and development efforts are more focused, efficient, and effective, it takes priority regional superior products that will have implications for the region to concentrate on these products so that the region becomes specialized which will ultimately increase regional income. Leading products are products that have the potential to be developed in an area by utilizing natural resources and local human resources that are market-oriented and environmentally friendly so that they have a competitive advantage and are ready to face global competition. Regional superior products illustrate the region's ability to produce products, create value, make real use of resources, provide employment opportunities, bring in income for the community and government, and have prospects for increasing productivity and investment.

The problem to be solved in this research is how to determine the criteria for regional superior products and determine the priority of superior fish agro-industry products in Banten Province in order to improve the competitiveness of processed fish products and subsequently increase regional competitiveness. A number of studies on the selection of superior products have been carried out using several methods, including Analytical Hierarchy Process / AHP (Kusdiana and Gunardi, 2014; Leo et al., 2014; Sandriana, 2015), MPE (Fasyah, 2016); LQ (Location Quetiont) (Dewi and Santoso, 2014; The Delphi Method (Herdhiansyah et al., 2013). In this study, the Eckenrode method is used to weight criteria for superior regional products. Next, to determine the priority of regional superior products, the TOPSIS method is used. TOPSIS does not have a specific input method in alternative measurements, for that TOPSIS requires input from other methods such as DEMATEL (Khanjankhani et al., 2016), fuzzy AHP (Sirisawat and Kiatcharoenpol, 2018) or ANP (Pourjavad and Shirouyehzad, 2015). In this study, TOPSIS was used as a complementary integration of the Eckenrode method that had been used in previous calculations.

\section{Methods:-}

In this research, primary data were obtained through stakeholder information and expert opinion. Information and expert knowledge are explored through expert survey methods by conducting in-depth interviews individually. The questionnaire was used as a tool in the interview to be directed. Secondary data were obtained from the Central Statistics Agency (BPS) and related government agencies in Banten Province. The stages of data collection and processing for weighting criteria using the Eckenrode method use the following steps (Ma'arif and Tanjung, 2003):

1. Respondents were asked to rank (for example, rank from $R_{1}$ to $R_{n}$, for example, there are $n$ ranks, $j=1,2,3$, ...., $n$; ranking to $j=R_{j}$ ) for each criterion (criteria $i$ denoted by $K_{i}$, there are as many as $n$ criteria, $i=1,2,3$, ...., n), so that the data as presented in Table 1 are obtained.

Table 1:- Calculation of Eckenrode Criteria Weight.

\begin{tabular}{|c|c|c|c|c|c|c|c|c|}
\hline Criteria & \multicolumn{6}{|c|}{ Rank } & Score & Weight \\
\hline & $\mathrm{R}_{1}$ & $\mathrm{R}_{2}$ & $\mathrm{R}_{3}$ & $\ldots$ & $R_{j}$ & $\mathrm{R}_{\mathrm{n}}$ & & \\
\hline $\mathrm{K}_{1}$ & $\mathrm{Jr}_{11}$ & $\mathrm{Jr}_{12}$ & $\mathrm{Jr}_{13}$ & $\ldots$ & & $\mathrm{Jr}_{1 \mathrm{n}}$ & $\mathrm{N}_{1}$ & $\mathrm{~B}_{1}$ \\
\hline $\mathrm{K}_{2}$ & $\mathrm{Jr}_{21}$ & $\mathrm{Jr}_{22}$ & $\mathrm{Jr}_{23}$ & $\ldots$ & & $\mathrm{Jr}_{2 \mathrm{n}}$ & $\mathrm{N}_{2}$ & $\mathrm{~B}_{2}$ \\
\hline $\mathrm{K}_{3}$ & $\mathrm{Jr}_{31}$ & $\mathrm{Jr}_{32}$ & $\mathrm{Jr}_{33}$ & $\ldots$ & & $\mathrm{Jr}_{3 \mathrm{n}}$ & $\mathrm{N}_{2}$ & $\mathrm{~B}_{3}$ \\
\hline$\ldots$ & $\ldots$ & $\ldots$ & $\ldots$ & $\ldots$ & & $\ldots$ & $\ldots$ & $\ldots$ \\
\hline $\mathrm{K}_{\mathrm{i}}$ & & & & & $\mathrm{Jr}_{\mathrm{ij}}$ & & & $\mathrm{B}_{\mathrm{i}}$ \\
\hline$\ldots$ & & & & & & & & \\
\hline $\mathrm{K}_{\mathrm{n}}$ & $\mathrm{Jr}_{\mathrm{n} 1}$ & $\mathrm{Jr}_{\mathrm{n} 2}$ & $\mathrm{Jr}_{\mathrm{n} 3}$ & $\ldots$ & & $\mathrm{J}_{\mathrm{mn}}$ & $\mathrm{N}_{\mathrm{n}}$ & $B_{n}$ \\
\hline & $\mathrm{R}_{\mathrm{n}-1}$ & $R_{n-2}$ & $R_{n-3}$ & $\ldots$ & $R_{n-j}$ & $R_{n-n}$ & Score Total & 1,00 \\
\hline $\mathrm{R}_{\mathrm{j}}$ & \multicolumn{8}{|c|}{ Rank order to $\mathrm{j}, \mathrm{j}=1,2,3, \ldots ., \mathrm{n}$} \\
\hline $\mathrm{K}_{\mathrm{i}}$ & \multicolumn{8}{|c|}{ : Criteria type to $\mathrm{i}, \mathrm{i}=1,2,3, \ldots, \mathrm{n}$} \\
\hline $\mathrm{J}_{\mathrm{rij}}$ & \multicolumn{8}{|c|}{ : Number of respondents who choose rank $\mathrm{j}$, for criteria $\mathrm{i}$} \\
\hline$R_{n-j}$ & \multicolumn{8}{|c|}{$\begin{array}{l}\text { Multiplier factor to } \mathrm{j} \text {, which is obtained from the reduction on the number of criteria or the } \\
\text { number of ranks }\end{array}$} \\
\hline $\mathrm{B}_{\mathrm{i}}$ & \multicolumn{8}{|c|}{ : The weight of criteria to $\mathrm{i}$} \\
\hline
\end{tabular}


Then based on $\mathrm{J}_{\mathrm{rij}}$ and $\mathrm{R}_{\mathrm{n}-\mathrm{j}}, \mathrm{N}_{\mathrm{i}}$ calculation is done as follows:

$\mathbf{N}_{\mathbf{i}}=\sum \mathbf{j}=\mathbf{1} \times \mathbf{R n}-\mathbf{j}, \mathbf{j}=1,2,3, \ldots \mathrm{n}$.

Total Score: $\sum_{\mathbf{i}=\mathbf{1}} \mathbf{N}_{\mathbf{i}}, \mathrm{i}=1,2,3, \ldots \mathrm{n}$.

Finally, calculating the weight of criteria $B_{i}\left(B_{1}, B_{2}, B_{3}, \ldots, B_{n}\right)$, where $i=1,2,3, \ldots, n$, using the formula:

$\mathbf{B}_{\mathrm{i}}=\left(\mathbf{N}_{\mathrm{i}} /\right.$ Total Score $)$.

After the weighting of the criteria is known, the selection of superior products is done by using the TOPSIS method.

In general, the TOPSIS procedure follows the steps as follows:

1. Make an alternative assessment matrix of the weighted criteria. If $\mathrm{A}$ is an alternative, $\mathrm{C}$ is an established criterion and $\mathrm{X}$ is an attribute of the criteria, then the table for presenting decisions is as follows:

Table 2:- The alternative criteria decision matrix.

\begin{tabular}{|c|c|c|c|c|c|c|}
\hline \multirow{2}{*}{ Alternatives } & \multicolumn{6}{|c|}{ Criteria } \\
\cline { 2 - 7 } & $\mathrm{C}_{1}$ & $\mathrm{C}_{2}$ & $\mathrm{C}_{3}$ & $\ldots \ldots$ & $\mathrm{C}_{\mathrm{j}}$ & $\mathrm{C}_{\mathrm{n}}$ \\
\hline $\mathrm{A}_{1}$ & $\mathrm{X}_{1,1}$ & $\mathrm{X}_{1,2}$ & $\mathrm{X}_{1,3}$ & $\ldots \ldots$ & $\mathrm{X}_{1, \mathrm{j}}$ & $\mathrm{X}_{1, \mathrm{n}}$ \\
\hline $\mathrm{A}_{2}$ & $\mathrm{X}_{2,1}$ & $\mathrm{X}_{2,2}$ & $\mathrm{X}_{2,3}$ & $\ldots \ldots$ & $\mathrm{X}_{2, \mathrm{j}}$ & $\mathrm{X}_{2, \mathrm{n}}$ \\
\hline$\ldots \ldots$ & $\ldots \ldots$ & $\ldots \ldots$ & $\ldots \ldots$ & $\ldots$ \\
\hline $\mathrm{A}_{\mathrm{i}}$ & $\mathrm{X}_{\mathrm{i}, 1}$ & $\mathrm{X}_{\mathrm{i}, 2}$ & $\mathrm{X}_{\mathrm{i}, 3}$ & $\ldots \ldots$ & $\mathrm{X}_{\mathrm{i}, \mathrm{i}}$ & $\mathrm{X}_{\mathrm{i}, \mathrm{n}}$ \\
\hline $\mathrm{A}_{\mathrm{m}}$ & $\mathrm{X}_{\mathrm{m}, 1}$ & $\mathrm{X}_{\mathrm{m}, 2}$ & $\mathrm{X}_{\mathrm{m}, 3}$ & $\ldots \ldots$ & $\mathrm{X}_{\mathrm{m}, \mathrm{j}}$ & $\mathrm{X}_{\mathrm{m}, \mathrm{n}}$ \\
\hline
\end{tabular}

2. Determine a normalized decision matrix. Normalization on each attribute of the decision matrix is done by comparing each attribute in an alternative with the root of the sum of the squares of each element on the same criteria in all alternatives. The equation for normalizing each attribute of the decision matrix is as follows

$\begin{aligned} \mathbf{r}_{\mathbf{i j}} & =\frac{\mathbf{x}_{\mathbf{i j}}}{\sqrt{\sum_{\mathrm{i}=1}^{\mathrm{m}} \mathbf{x}_{\mathbf{i j}}^{2}}} \ldots \ldots \ldots \ldots \ldots \ldots \ldots \ldots \ldots \ldots \ldots \ldots \ldots \ldots \ldots \ldots \ldots \\ \mathrm{r}_{\mathrm{ij}} & =\text { result of normalization } \\ \mathrm{x}_{\mathrm{ij}} & =\text { the weight of the } \mathrm{j}^{\text {th }} \text { criteria on the } \mathrm{i}^{\text {th }} \text { alternative } \\ \mathrm{i} & =\mathrm{i}^{\text {th }} \text { alternative } \quad \mathrm{i}=1,2, \ldots \ldots \mathrm{m} \\ \mathrm{j} & =\mathrm{j}^{\text {th }} \text { criteria } \quad \mathrm{j}=1,2, \ldots \ldots \mathrm{n}\end{aligned}$

3. Calculate a weighted normalized decision matrix using Equation 6.

$\mathbf{y}_{\mathbf{i j}}=\mathbf{w}_{\mathbf{j}} \mathbf{r}_{\mathbf{i j}}$

$\mathrm{y}_{\mathrm{ij}}=$ weighted normalization decision matrix

$\mathrm{w}_{\mathrm{j}}=$ declare the weight of the $\mathrm{j}^{\text {th }}$ criteria

$\mathrm{r}_{\mathrm{ij}}=$ normalized matrix value

$\mathrm{i}=\mathrm{i}^{\text {th }}$ alternative $\mathrm{i}=1,2, \ldots \mathrm{m}$

$\mathrm{j}=\mathrm{j}^{\text {th }}$ criteria $\mathrm{j}=1,2, \ldots . \mathrm{n}$

The weight of each criterion is taken from the results of the previous calculation using the Eckenrode method.

4. Calculate the positive ideal solution matrix and the negative ideal solution matrix. From the weighted normalized matrix data, positive ideal solutions $\left(\mathrm{A}^{+}\right)$and negative ideal solutions $\left(\mathrm{A}^{-}\right)$are determined. To determine the ideal solution, first determine the attributes in each criterion, such as the benefit attribute or cost attribute.

\begin{tabular}{|c|c|c|c|c|}
\hline \multicolumn{2}{|c|}{ If the attribute is profit (benefit) } & $y_{j}^{+}=\left\{\begin{array}{l}\max y_{i j} \\
\min y_{i j}\end{array}\right.$ & & (6) \\
\hline If the attribute is cost & & $y_{j}^{-}=\left\{\begin{array}{l}\min y_{i j} \\
\max y_{i j}\end{array}\right.$ & & $(7)$ \\
\hline $\mathrm{A}^{+}=\left(\mathrm{y}_{1}^{+}, \mathrm{y}_{2}^{+}, \ldots \mathrm{y}_{\mathrm{n}}^{+}\right)$ & \multicolumn{3}{|c|}{ 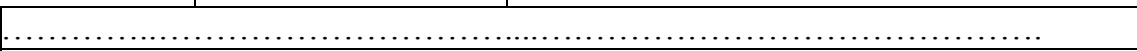 } & $(8)$ \\
\hline$A^{-}=\left(y_{1}^{-}, y_{2}^{-}, \ldots y_{n}^{-}\right)$ & \multicolumn{3}{|c|}{ 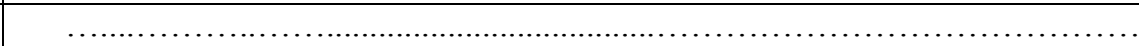 } & $(9)$ \\
\hline
\end{tabular}

5. Determine positive ideal solutions and negative ideal solutions. The positive ideal solution is defined as the sum of all the best values that can be achieved for each attribute, while the negative-ideal solution consists of all the 
worst values that can be achieved for each attribute. The alternative distance Ai with a positive ideal solution is obtained through the formula:

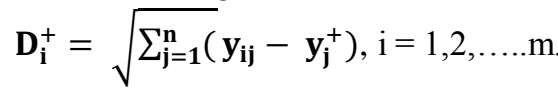

The alternative distance $A_{i}$ with a negative ideal solution is obtained through the formula:

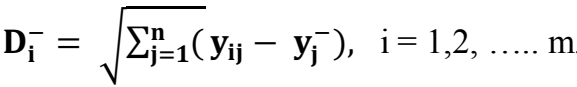

6. Topsis considers a positive ideal solution and a negative ideal solution by taking a closeness relative to a positive ideal solution. Preference values for each alternative (Vi) are obtained through the formula:

$\mathbf{v}_{\mathbf{i}}=\frac{\mathbf{D}_{\mathbf{i}}^{-}}{\mathbf{D}_{\mathbf{i}}^{-}-\mathbf{D}_{\mathbf{i}}^{+}}, \mathbf{i}=1,2, \ldots \ldots \mathrm{m}$.

\section{Results and Discussion:-}

Determination of Superior Product Criteria using the Eckenrode method:

Here in Figure 1 is presented a mapping of the criteria for determining superior products in previous studies and new criteria used in this study.

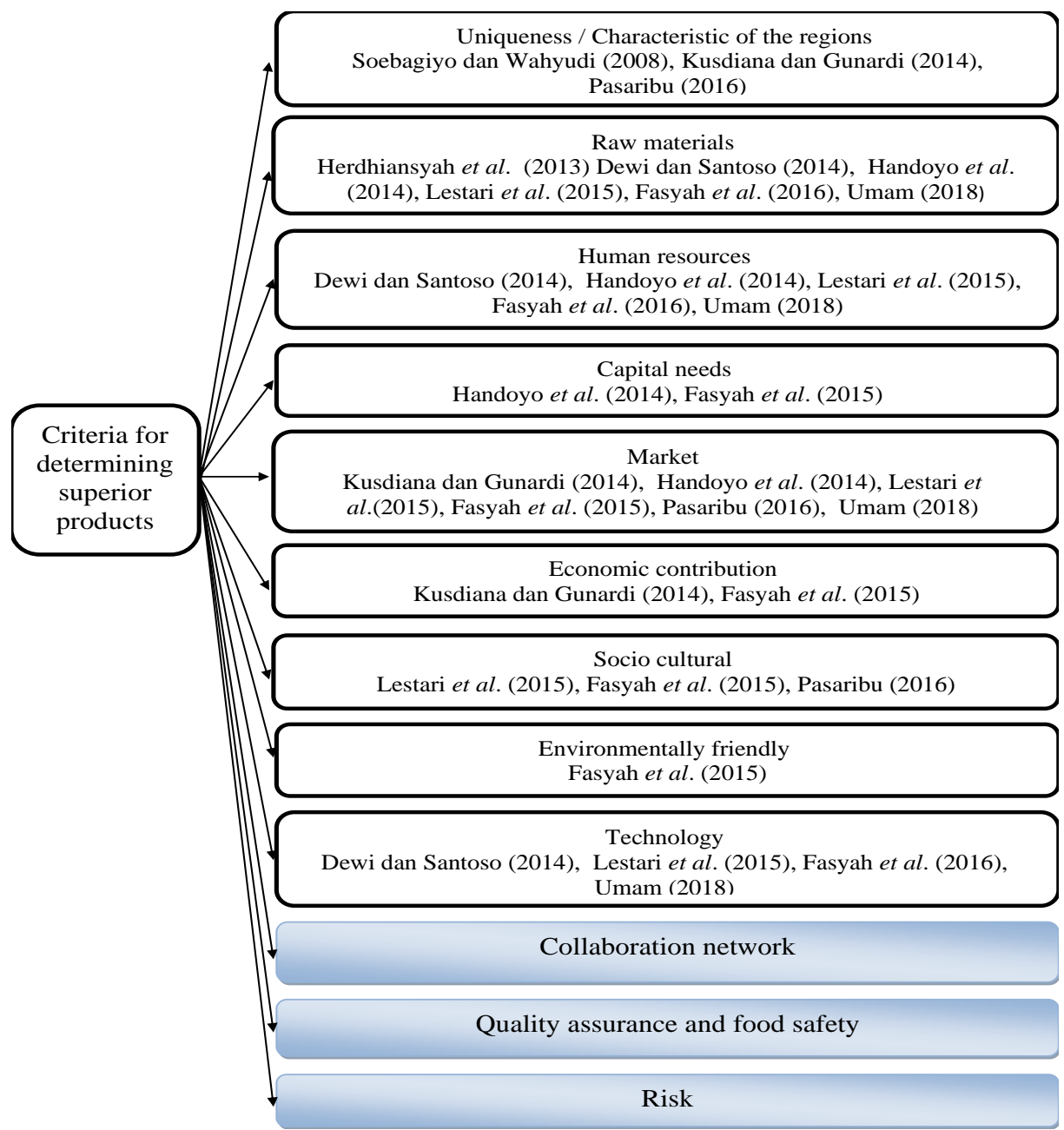

Figure 1:- Mapping of superior product criteria in this study and in previous studies.

From the results of interviews and informal discussions, a number of criteria will be used to determine the priority of superior processed fish products in Banten Province, namely the uniqueness or characteristics of the region, raw materials, human resources, technology, market availability, economic contribution, socio-cultural contribution, 
environmentally friendly, plus three criteria that had not been used as superior product criteria, namely collaboration networks, quality assurance, and food safety, and risk.

Collaborative networks can encourage innovation through collaboration between academia, government, companies, and civil society so as to enhance economic growth (Afonso et al., 2010; Ranatiwi and Mulyana, 2018). Through collaboration networks, small industries will collaborate with other companies to improve their ability to access and absorb innovation. Although the processing technology has developed rapidly, traditional or small-scale processors generally still do not pay enough attention to the quality and safety issues of the products produced. In fact, the fisheries product market at the domestic and global levels currently requires quality standards, uniformity of size, and product innovation (Bashir et al., 2019). So, the quality assurance and food safety criteria of a product are one of the important requirements so that food products can be accepted by the wider market.

For agro-industry companies, there are a number of risks in each stage, starting from the stage of supplying raw materials, processing, and even marketing. According to Jacq et al. (2010), the risk of procuring raw materials is one of the most important aspects of the agro-industry risk assessment. This is mainly due to the seasonal nature of agricultural products, which are easily damaged, varied, and have a large volume. Small and medium businesses have a high risk due to limited resources (Verbano and Venturini, 2013). From the results of data processing using the Eckenrode method, we obtained criteria weights for the determination of superior processed fish products in Banten Province. Complete criteria for superior products and their weight are presented in the following table.

Table 3:- Priority criteria for superior processed fish products in Banten Province.

\begin{tabular}{|c|l|c|}
\hline \multicolumn{1}{|c|}{ Criteria } & Weight \\
\hline Priorities & \multicolumn{1}{|c|}{} & 0.121 \\
\hline 1 & Uniqueness /regional characteristics (K1) & 0.102 \\
\hline 2 & Raw material (K2) & 0.099 \\
\hline 3 & Market absorption (K5) & 0.097 \\
\hline 4 & Collaboration network (K9) & 0.096 \\
\hline 5 & Technology (K4) & 0.085 \\
\hline 6 & Human resources (K3) & 0.079 \\
\hline 7 & Economic contribution (K6) & 0.076 \\
\hline 8 & Environmentally friendly (K8) & 0.070 \\
\hline 10 & Socio cultural contribution (K7) & 0.061 \\
\hline 11 & Quality assurance and food safety (0.061) (K10) & 0.058 \\
\hline 12 & Risk (K12) & 0.056 \\
\hline
\end{tabular}

In determining the priority criteria used in determining superior products, the highest weight is owned by the criteria of uniqueness or regional characteristics (0.121). The uniqueness or characteristic of a region is a factor that represents a measure of the uniqueness or identity of the region, based on the potential of local resources. The more distinctive a commodity is, it makes it more memorable and superior in the market. The product will be identical to the area so that it will be remembered by consumers and tourists who visit and make it as a sign or a souvenir as a sign of having visited the area. Next to the second priority is the criteria for raw materials with a weight of 0.102 . The sustainability of the fish processing industry as one form of agro-industry is determined by the ability to procure raw materials, in this case, fresh fish as the main raw material. To ensure the smooth production process, it is needed the availability of fish in sufficient quantities and with good quality standards. Market criteria are at the third priority with a weight of 0.099. The market illustrates that the superior products of an area must have the ability to be accepted and respond to market needs. The wider the market range, the higher the potential for the product to be superior.

Determination of priority products using the TOPSIS method:

The following are presented in table 4 results of calculations that have been carried out so as to produce an index that shows the priority order of superior processed fish products in Banten Province.

Table 4:- Priorities of superior processed fish products in Banten Province.

\begin{tabular}{|c|l|c|}
\hline \multicolumn{1}{|c|}{ Product } & Index \\
\hline 1 & Milkfish satay & 0.976 \\
\hline 2 & Fish meatballs & 0.776 \\
\hline
\end{tabular}




\begin{tabular}{|c|l|c|}
\hline 3 & Pindang & 0.758 \\
\hline 4 & Fish meatball crackers & 0.747 \\
\hline 5 & Otak-otak & 0.739 \\
\hline 6 & Salted fish & 0.711 \\
\hline 7 & Fish nugget & 0.693 \\
\hline 8 & Shredded fish & 0.671 \\
\hline 9 & Fish crackers & 0.658 \\
\hline 10 & Siomay & 0.617 \\
\hline
\end{tabular}

From the results of calculations with the TOPSIS method, obtain the results that the first priority of superior processed fish products from Banten Province is milk satay. Milkfish satay has been widely known as a typical dish from Banten Province. Called satay because milkfish that have been processed, clamped with bamboo, then burned so that it resembles satay. From the criteria of product characteristics/uniqueness, satay milkfish have a high originality value because it is an authentic cuisine menu from the Banten region which has its own historical value. That said, this cuisine is an idea of the King of Banten Region who wants to present milkfish dishes to guests without having to bother guests to separate the bones of milkfish from their meat. Since then, milkfish satay began to be known and became a special menu of the kingdom of Banten.

\section{Conclusions: -}

Criteria for superior fish processing agroindustry products are regional uniqueness $(0.121)$, raw materials $(0.102)$, market absorption (0.099), collaboration network (0.097), technology (0.096), human resources (0.085), economic contribution (0.079), environmentally friendly (0.076), socio-cultural contributions (0.070), quality assurance and food safety $(0.061)$, risk $(0.058)$, and working capital $(0.056)$. While the priority of superior processed fish products from Banten Province is milkfish satay.

\section{References:-}

1. Afonso, O., Monteiro, S., Thomson, M. (2010). A Growth Model for the Quadruple Helix Innovation Theory. J Business Economics and Management. 13(4):1-31.

2. Alfarisi, M.N., Anggraeni, D., Sariyoga, S. (2018). Strategi pengembangan produk olahan ikan lele (Clarias Sp) (Suatu kasus di UKM Mae Shetie dan UKM Abon Ikan Lele Kota Cilegon). Jurnal Agribisnis Terpadu. 11(1):68-79

3. Anggraeni, S.K., Maarif, M.S., Sukardi, Raharja, S. 2017. Strategi peningkatan daya saing usaha kecil menengah berbasis olahan ikan di Indonesia: suatu tinjauan. Jurnal. Industral Services. 3(1): 331-341.

4. Dewi, K.A.N.P., Santoso, E.B. (2014). Pengembangan Komoditas Unggulan Sektor Pertanian Tanaman Pangan di Kabupaten Karangasem Melalui Pendekatan Agribisnis. Jurnal Teknik Pomits. 3 (2): 184-189. http://dx.doi.org/10.12962/ j23373539.v3i2.7265

5. Fasyah, D.N., Daryanto H.K., Suprayitno, G. (2016). Penentuan produk unggulan usaha mikro kecil menengah sektor industri agro di Kabupaten Bogor. MIKM. 11(2):103-110.

6. Handoyo E., Cahyani A.D., Yunitarini, R. (2014). Sistem pendukung keputusan pemilihan produk unggulan daerah menggunakan metode Entropy dan Electre II (Studi kasus: Dinas Koperasi, Industri dan Perdagangan Kabupaten Lamongan). J Teknol Technoscient. 7(1):22-27.

7. Hasibuan, S. (2015). SMEs development strategy for competitive and sustainable typical local snacks of Banten Province. I J Advanc Scien Engineer Informat Tech. 5(6):410-414.

8. Herdhiansyah, D., Sutiarso, L., Purwadi, Taryono, D. (2013). Kriteria Kualitatif Penentuan Produk Unggulan Komoditas Perkebunan dengan Metode Delphi di Kabupaten Kolaka Sulawesi Tenggara. Jurnal Agritech. 33 (1): 60-69. doi.org/10.22146/agritech.9568

9. Jacq E.G., Udayana, I.G.B., Eriyatno, Hambali, E., Fauzi, A.M. (2010). Pengembangan model kelembagaan sebagai solusi mengatasi risiko agroindustri biodiesel berbasis kelapa sawit. Agritek. 11(2):10-20.

10. Khanjankhani, K., Rafiei, S., Ezzatabadi, M., Askari, R., Abooee, F., Shafii, M. (2016). Evaluation and Prioritization of Service Quality Dimensions Using Dematel and Topsis (A Case Study in Iran). Bali Medical Journal. 5(2):298-302. DOI:10.15562/bmj.v5i2.233

11. Kusdiana, D., Gunardi, A. 2014. Pengembangan produk unggulan UMKM Kabupaten Sukabumi. J Trikonom. 13(2):153-171.

12. Leo, J., Nababan, E., Gultom, P. (2014). Penentuan Komoditas Unggulan Pertanian dengan Metode Analytical Hierarchy Process (AHP). Saintia Matematika. 2(3): 213-224. 
13. Lestari, D., Sukiyono, K., Badrudin, R. (2015). Strategi pengembangan pemasaran industri rumah tangga Raflesia di Desa Sumber Agung Kecamatan Arma Jaya Kabupaten Bengkulu Utara. AGRISEP. 15(2): 147 158

14. Maarif, M.S., dan Tanjung, H. (2003). Teknik-teknik kuantitatif untuk manajemen. Jakarta: Penerbit PT Gamedia Widiasarana Indonesia.

15. Pourjavad, E., Shirouyehzad, H. (2015). Evaluation of manufacturing lines in a mining industry by ANP and TOPSIS. Int. J. Manufacturing Technology and Management. 29(3):235-251.

16. Ranatiwi, M., Mulyana. (2018). Dampak jejaring kolaborasi dan kapabilitas inovasi terhadap kinerja. EKOBIS. 19(1): 49 - 58

17. Ridloudin, A., Raharja, S., Suharyadi. (2019). Strategi Peningkatan Daya Saing Ikan Bandeng Olahan Di Kota Serang Banten. MIKM. 14(1): 76-82.

18. Sandriana, N., Hakim, A., Saleh, C. (2015). Strategi Pengembangan Produk Unggulan Daerah Berbasis Klaster di Kota Malang. Jurnal Reformasi. 5(1): 89-100.

19. Sirisawat, P., Kiatcharoenpol, T. (2018). Fuzzy AHP-TOPSIS approaches to prioritizing solutions for reverse logistics barriers. Computers \& Industrial Engineering. 117:303-318. doi:10.1016/j.cie.2018.01.015

20. Umam, K., Sulastri, V.E., Andini, T., Sutiksno, D.U., Mesran. (2018). Perancangan sistem pendukung keputusan penentuan prioritas produk unggulan daerah menggunakan metode VIKOR. JURIKOM. 5(1): 43-49.

21. Verbano, C., Venturini, K. (2013). Managing risks in SMEs: a literature review and research agenda. JTMI. 8(3):33-34. doi:10.4067/s0718-27242013000400017. 